\title{
The Nature of Teacher Professional Misconduct in Tanzanian Public Primary Schools: The Case of Sumbawanga Municipal and Rural Districts
}

\author{
Oziambo Betweli ${ }^{1, *}$ \\ ${ }^{1}$ Department of Educational Foundations and Management, Dar es Salaam University \\ College of Education, Tanzania \\ *Correspondence: Department of Educational Foundations and Management, Dar es Salaam \\ University College of Education, PO Box 2329 Dar es Salaam, Tanzania \\ Tel: 255-784- 851-438Ｅ-mail: katiti80@yahoo.co.uk
}

Received: December 17, 2012 Accepted: February 2, 2013 Published: February 23, 2013

doi:10.5296/ije.v5i1.3291ＵRL: http://dx.doi.org/10.5296/ije.v5i1.3291

\begin{abstract}
This paper investigates the nature of teacher professional misconduct in Tanzanian public primary schools. It involves views and/or experience from different groups of stakeholders in education in Rukwa Region, more specifically in Sumbawanga Municipal and Rural Districts. The paper employed both qualitative and quantitative approaches which were informed by a case study design. Data relevant to this paper were collected through interviews, questionnaires, document analysis, and observation checklists. The paper reveals that, first; teacher professional misconduct was prevalent in both rural and urban settings in Rukwa Region with some variation in terms of type, cause, and frequency. Secondly, the variation of teacher misconduct in schools was greatly influenced by teacher's sex, work experience, and level of education. In view of the research findings recounted, the paper concludes that teacher misconduct is a problem of great concern in both rural and urban schools that affects teachers' work performance, the teaching, and learning process, and the quality of education at large.
\end{abstract}

Keywords: teacher; professional misconduct; public primary schools; Tanzania; Sumbawanga 


\section{Introduction}

Teachers play a vital role in the attainment of goals in education in any nation. They are responsible for high standards in education, transmission of national values and norms to their pupils by teaching them and/or being good models. Teachers are the transmitters of knowledge who ensure that children learn, they are role models to students, and in most rural communities, they are the most educated and respected personages (Patrinos \& Kagia, 2008). They are at the front line of developing pupils' understanding, skills, learning and core values. Teachers are, therefore, the most important elements in producing quality education, thus, they are expected to abide by the professional code of ethics.

However, in spite of such values and importance attached to teachers and the teaching profession, there are professional misconduct and lack of integrity amongst teachers that appear to be incompatible with the goals towards the attainment of quality education. Teacher misconduct disturbs the implementation of the planned interventions, particularly the correct functioning of the teaching and learning process (van Nuland \& Khandelwal, 2006). Literature shows that a large number of teachers and other educational administrators have been engaging in various unethical practices across the world.

In North America, U.S.A in particular, some incidences of educators' sexual misconduct such as sexual touching, request for sexual favour and unwelcome sexual advance have been revealed by students in various parts of the country (Shakeshaft, 2004). Similarly, European countries experience several problems related to teacher unethical practices. In Germany for example, some teachers are involved in selling examination questions and marks, selling front-row seats to students in large classes and forcing students to buy certain materials or additional materials to take private lessons (Chapman, 2002). In Asian countries, China and Bangladesh in particular, the rate of teacher misconduct has been increasing tremendously. Teachers are reported to engage in selling examination papers or allowing someone else to take the examination for a certain candidate (Transparency International, 2007; Bray, 2003; Bray, 1999).

In Africa, the Sub-Saharan countries experience more problems of professional misconduct among teachers and other educational administrators. Teacher misconduct and unprofessionalism, together with corruption among education administrators threatens to undermine the current initiatives to improve educational quality in many low-income countries, including most of Sub-Saharan Africa (Anangisye \& Barrett, 2006).

In Tanzania, the incidents of teacher misconduct can be traced through various studies which were previously done in the country. Boimanda (2004) and Anangisye (2006) unveil teachers' professional malpractices that are commonly practised by teachers. These include immoral conduct, absenteeism, corruption, private tuition, unethical dressing, examination fraud, and sexual misconduct. Similarly, mass media such as radios, televisions, and newspapers reveal several forms of misconduct committed by teachers in different parts of the country. For example, male teachers are accused of having sexual relationships with their female students (Kuleana, 1999). 
As a result of persistent teacher misconduct, in particular absenteeism and lateness or not showing up for work, the former Bukoba District Commissioner ordered 19 teachers to be caned publicly (BBC News, February 13, 2009). In the same vein, the Teachers' Services Department (TSD) in Tanzania that deals with teachers' disciplinary issues related to professional misconduct dismisses 200 to 300 teachers every year for various professional misconducts (TSD, 2008).

\subsection{Statement of the Problem}

The quality of education in any nation depends much upon the quality of its teachers, since teachers are among the key elements in the attainment of educational goals. The persistent increase in teacher misconduct in schools has been impeding the progress towards implementation of educational goals, particularly Education for All (EFA) and Millennium Development Goals (MDGs). In spite of various measures taken by the Teachers' Service Department such as warnings and reprimands, and dismissing teachers from service on misconduct grounds, the problem of teacher misconduct among schools in the country is still rampant.

\subsection{Purpose of the Study}

The purpose of this study was to examine the nature of teacher professional misconduct in public primary schools in Tanzania. More specifically the study sought to:

i. Identify the types of teacher misconduct commonly practiced by teachers in schools.

ii. Find out the causes of teacher misconduct in schools

iii. Examine the variation of teacher misconduct in schools.

\section{Research Methods}

\subsection{Research Design}

The study employed mainly a qualitative approach with some aspects of quantitative approach. Qualitative research entails a means for exploring and understanding the meaning individuals or groups ascribed to a social human problem (Creswell, 2009). The qualitative approach dominated a large part of this study as the study sought to generate the general theme from the analysis and interpretation of the collected data on the nature of teacher professional misconduct in Tanzanian Public Primary Schools. Thus, it facilitated in gathering direct opinions of participants through interviews and observation checklists. On the other hand, the quantitative approach which is more interested in numbers and statistical procedures was adopted to complement the study. For this matter, both qualitative and quantitative approaches were informed by a case study design.

\subsection{Geographical Location of the Study}

The study was conducted in Rukwa Region, located in the South-Western part of Tanzania in the Southern Highlands Zone which comprises of three regions, namely Mbeya, Iringa and 
Rukwa. According to TSD (2008) Rukwa is among the leading regions in terms of cases of teacher misconduct in the country. More specifically, two districts namely Sumbawanga Municipal and Rural were involved in the study since according to data from TSD Regional Office the two districts appeared to have many cases of teacher misconduct compared to the rest. This condition justified the selection of Rukwa Region to be involved in this study.

\subsection{Target Population}

The target population of this study included 232 participants obtained from 4 administrative wards and 10 primary schools in both Sumbawanga Municipal and Rural Districts. In particular, the sample consisted of 2 District Education Officers, 2 District Chief Teachers' Service Department Officers, 2 District Chief School Inspectors, 4 Ward Education Coordinators, 10 headteachers, 12 School Management Committee representatives, 100 teachers, and 100 pupils. These varied groups of participants provided the researcher with sufficient information on the nature of teacher professional misconduct in their respective schools.

\subsection{Sample and Sampling Techniques}

'The question of sampling arise directly out of the issue defining the population on which the research will focus' (Cohen et al, 2011). Best and Khan (2006) posit that the size of adequate sample depends upon the nature of the population of interest for the study. In the present study, the selection of the sample considered different factors such as the information required, the purpose of the study and the time frame. The study employed three types of sampling techniques, namely simple random, purposive and stratified sampling. Teacher and student participants were selected through both stratified and simple random sampling. On the other hand, District Educational Officers, District Chief School Inspectors, District Chief Teachers Services Department Officers, Ward Education Coordinators, Headteachers and School Management Committee Representatives were obtained through purposive sampling.

\subsection{Data Collection}

In this study the following methods were employed to collect information. These included document analysis, observation, semi-structured interview administered to District Education Officers, District Chief Teachers' Service Department Officers, District Chief School Inspectors, Ward Education Coordinators, headteachers and School Management Committee representatives, and questionnaires administered to teachers and pupils.

\section{Results and Discussion}

\subsection{Types of Teacher Misconduct}

Participants were asked to identify types of teacher misconduct common in their respective schools. Findings are summarized in Table 1. 
Table 1: Teachers' and pupils' responses on the teacher misconduct by type, location, frequency and percent

\begin{tabular}{llccc}
\hline Type of misconduct & Rural & \multicolumn{3}{c}{ Urban } \\
\hline & Teachers (\%) & Pupils (\%) & Teachers (\%) & Pupils (\%) \\
\cline { 2 - 5 } Absenteeism & $37(74)$ & $40(80)$ & $44(88)$ & $47(94)$ \\
Drunkenness & $41(82)$ & $47(94)$ & $24(48)$ & $26(52)$ \\
Sexual abuse & $17(34)$ & $23(46)$ & $7(14)$ & $13(26)$ \\
Examination fraud & $11(22)$ & $17(34)$ & $9(18)$ & $14(28)$ \\
Abusive language & - & - & $27(54)$ & $26(52)$ \\
Drug abuse & $7(14)$ & $13(26)$ & - & - \\
Unethical dressing & - & - & $26(52)$ & $30(60)$ \\
\hline
\end{tabular}

Looking at the data in Table 1, the following observations are made. Firstly, it is evident that teacher misconduct in both Sumbawanga Municipal and Rural Districts was rampant as the majority of the pupil and teacher respondents indicated the existence of teacher misconduct in their respective schools. Secondly, teachers' use of abusive language and unethical dressing were common in urban schools only. More than half of the pupil and teacher respondents in urban settings indicated that, the use of abusive language and unethical dressing were common practice among teachers in their schools.

Thirdly, the drug abuse problem was also indicated to exist among teachers in rural based schools especially the use of marijuana was common and attributable to the fact that most of the indigenous people in rural areas used to grow and smoke marijuana. Teachers adopted such misconduct as they interacted and established friendship with various groups of people who used to smoke marijuana and some were also native to local community having grown up in that environment.

Fourthly, absenteeism was prevalent in both urban and rural schools. More than three quarters of pupil and teacher respondents in both rural and urban settings indicated that absenteeism was a problem. Similarly, during interviews held with headteachers it was reported that teachers spent few work hours at school and used the rest of their time in private businesses. Absenteeism was attributable to low income due to low salaries. As a result, teachers used official hours to engage in private activities to supplement their meagre income. This finding is in line with Barrett (2004a) who points out that in Tanzania teacher absenteeism tends to increase when teachers run out of money. Similarly, the study by HakiElimu (2010) revealed that in the visited primary schools the rate of teacher absenteeism was $10 \%$. Teacher absenteeism was viewed by participants as leading to failure to complete curriculum implementation and poor academic performance amongst pupils.

Fifthly, drunkenness was a problem among teachers in rural schools. Most of interviewees in rural areas particularly the School Management Committee representatives, headteachers and Teachers' Service Department Officers disclosed that drunkenness was the problem that affected a large number of teachers in their schools: 
"Drunkenness is a major problem that affects the majority of teachers in this school...Most of them have forgotten their professional role and fallen into drunkenness. They use most of their time in drinking local beers... Some of them have established their own bars selling local brews!" [Rural school, School Management Committee representative]

The above quote indicates that drunkenness problem is rampant among rural based schools, thus affecting teachers' professional behaviour. This finding concurs with Barrett (2004b) who estimates that as many as 1 in 7 male teachers at rural schools have a drunkenness problem. Similarly, findings in this study indicated that teachers developed drunkenness problems when they became more familiar with and integrated into rural communities since selling and drinking local brews were viewed as part of socio- economic activities in rural areas. Moreover, the prices for local brews were relatively cheaper compared to those of modern beers. It ranged from TSH 200 to 300 per litre. Such price made it possible for the majority of teachers to be attracted to it with their little income.

\subsection{Variations of Teacher Misconduct}

The study wanted to examine variations of teacher misconduct in relation to teachers' sex, work experience and/or level of education. The findings regarding this objective were obtained through both questionnaires administered to teachers and pupils, and interviews administered to headteachers, Ward Education Coordinators, School Management Committee representatives, DEOs, District Chief TSD Officers and School inspectors.

\subsubsection{Variation in Relation to Teachers' Sex}

Teachers and pupils were asked to identify the category of teachers who indulged most in misconduct. The aim was to compare the rate of misconduct between female and male teachers so as to identify reasons for the variations. The findings are indicated in Figure 1.

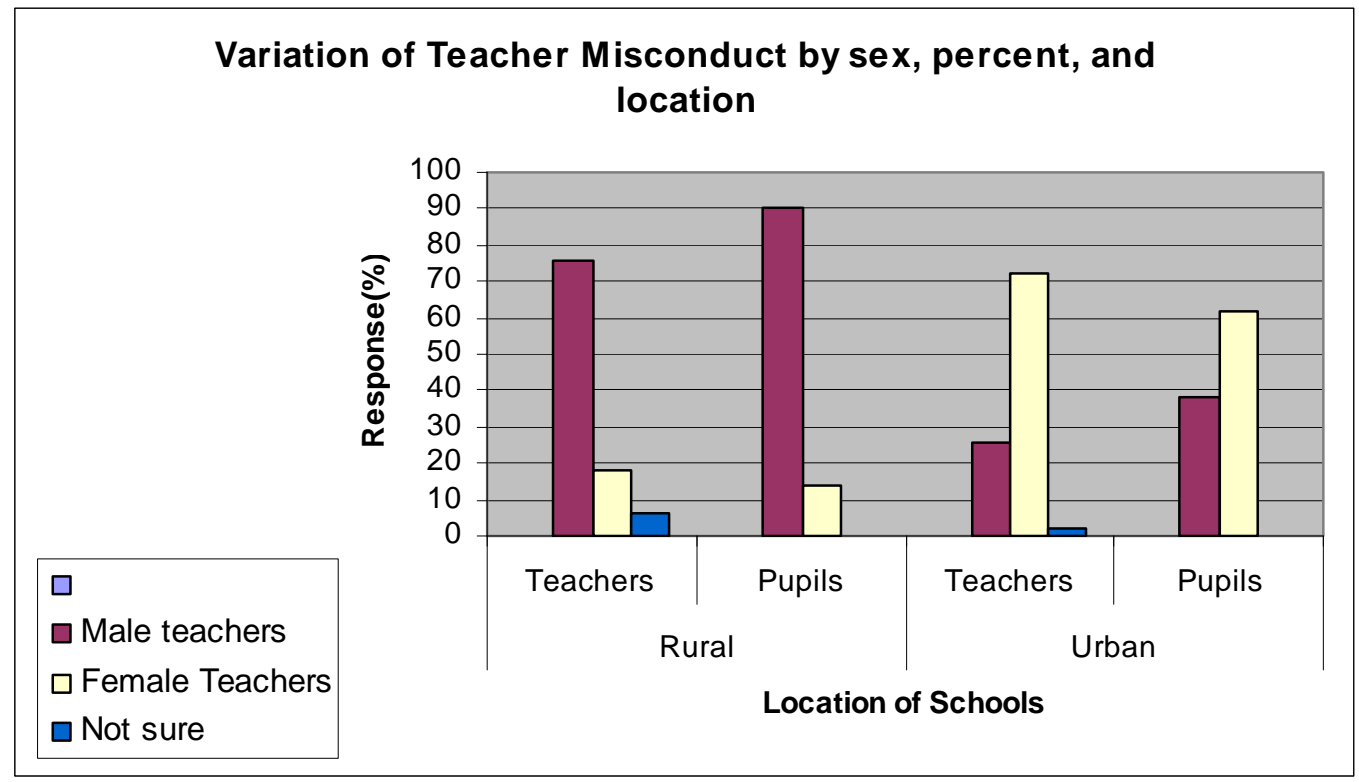

Figure 1: Variation of Teacher Misconduct by sex, percent, and location 
The results from Figure 1 indicate great variations of teacher misconduct in schools between male and female teachers. In rural schools the frequency of committing misconduct was higher among male teachers than female ones. Consider the experience by the Rural District Chief Teachers' Service Department Officer:

"Most of the complaints and cases that I get from headteachers in rural schools involve male teachers who behave unprofessionally. Only in few occasions I receive cases related to female. For instance, in 2008 out of 11 cases 8 involved male teachers"

The deployment of more male teachers than female in rural schools was one of the possible factors for such variation. Also, it was revealed that male teachers were not quick to change their unprofessional practices compared to their counterpart female teachers. Unlike those in rural areas, female teachers in urban areas were indicated to have more cases of misconduct than male counterparts. Possible reasons for such variation among others, was that most of the female teachers posted in urban schools had relationships with other top government officials within and outside the municipality such as being wives, daughters and nieces. Findings showed that female teachers took advantage of those relationships to become lax and misbehave at work. Such teachers knew that even if their supervisor headteachers reported them to Ward Education Coordinators or District Education Officers, no serious action would be taken against them. The forms of misconduct commonly committed by female teachers among urban schools included slovenly dressing, lateness, and absenteeism. The rate of teacher misconduct between male and female teachers varied depending on type of work location (rural for male) and relationships with people in high offices (more in urban for female).

\subsubsection{Variation in Relation to Teachers' Work Experience}

Teacher participants were asked to tell whether or not teacher misconduct varied according to teachers' work experience. Table 2 summarizes the findings.

Table 2: Teacher responses on variation of teacher misconduct by teachers' work experience, frequency, percent and location of school

\begin{tabular}{lcccc}
\hline Teachers' work experience & \multicolumn{2}{c}{ Rural } & \multicolumn{2}{c}{ Municipal } \\
\hline (Years) & $\mathrm{N}=50$ & $(\%)$ & $\mathrm{N}=50$ & $(\%)$ \\
\hline $0-5$ & 4 & 8 & 18 & 36 \\
$6-10$ & 13 & 26 & 17 & 34 \\
$11+$ Above & 33 & 66 & 15 & 30 \\
\hline
\end{tabular}

The findings in Table 2 indicate that in rural schools the rate of teacher misconduct was believed to increase as teachers became more experienced in the teaching profession. During interviews, headteachers in particular the newly appointed ones disclosed that most of the experienced teachers failed to conform to headteachers' directives. One of the major reasons was that the experienced teachers took advantage of their experience in the profession and school environment to water down headteachers' instructions on good conduct as the headteacher of one of the rural primary schools revealed that: 
"....Indeed, experienced teachers ignore the way they are supposed to behave professionally, I use much effort to remind them to act in professional way... They view me as too young to instruct them, sometimes they tell me "You little boy we have been in this profession since Mwalimu Nyerere's era, even before you were born- what do you want to tell us!".

In urban schools less experienced teachers were singled out to commit misconduct than those with more professional experience. Findings unveiled the teachers' high expectations after being employed as one of the possible factors that made the less experienced teachers to engage in misconduct. Most of the newly recruited teachers had high socio-economic expectations such as high salaries with regard to their employment. However, when things went opposite teachers lost job commitment. Others lost their job morale as the government failed to fulfill their needs and demands such as when delaying to pay their first salaries and subsistence allowances.

\subsubsection{Variation in Relation to Teachers' Level of Education}

Teacher respondents were asked to identify among the categories of teachers who were implicated more in misconduct cases in relation to teachers' level of education. Findings are presented in Table 3.

Table 3: Variations of teacher misconduct by teachers' level of education, frequency, percent and location of school

\begin{tabular}{lcccc}
\hline Teachers' indulgence in misconduct & \multicolumn{2}{c}{ Rural } & \multicolumn{2}{c}{ Municipal } \\
\hline (Level of education) & $\mathrm{N}=50$ & $(\%)$ & $\mathrm{N}=50$ & $(\%)$ \\
\hline Grade A (Trained for 2 years) & 5 & 10 & 4 & 8 \\
Grade A (Trained for 1 year) & 27 & 54 & 31 & 62 \\
Grade B/C & 11 & 22 & 9 & 18 \\
Diploma & 3 & 6 & 2 & 4 \\
Degree & - & - & 1 & 2 \\
No response & 4 & 8 & 3 & 6 \\
\hline Total & $\mathbf{5 0}$ & $\mathbf{1 0 0}$ & $\mathbf{5 0}$ & $\mathbf{1 0 0}$ \\
\hline
\end{tabular}

Data in Table 3 indicate the following observations. First, there were variations of teacher misconduct in relation to teachers' level of education in both rural and urban schools. Teachers with Grade 'A' Certificates particularly those who underwent teacher education courses for one year were the most vulnerable to misconduct. Teacher respondents in both settings admitted to observe more cases of misconduct involving Grade 'A' (1 year) Certificate holders than other categories.

Also during interviews held with headteachers it was revealed that most of the teachers recruited during the implementation period of the Primary Education Development Program (PEDP) in the 2000s were professionally incompetent. During that period teachers were trained for only one year instead of the normal two years. Most of the participants indicated that teachers with little professional knowledge were produced during PEDP implementation. As a result, when they were posted to schools most of them failed to abide by the professional 
ethics. It was claimed that cases of teacher misconduct decreased with teachers' higher level of professional training. Teachers who possessed Grade 'A' (2 years) Certificates, Diploma in Education and those with Degree were less involved in misconduct compared to Grade ' $A$ ' (1 year) and 'B/C' Certificate holders.

\subsection{Causes of Teacher Misconduct in Schools}

Participants through questionnaires and interviews were asked to point out possible causes of teacher misconduct in their schools. Findings are summarized and presented in Table 4.

Table 4: Teacher misconduct by causes, location, frequency, and percent

\begin{tabular}{lcccc}
\hline Cause of teacher misconduct in schools & \multicolumn{2}{c}{ Rural } & \multicolumn{2}{c}{ Municipal } \\
\cline { 2 - 6 } & $\mathrm{N}=50$ & $(\%)$ & $\mathrm{N}=50$ & $(\%)$ \\
\cline { 2 - 6 } Poor living environment & 36 & 72 & 39 & 78 \\
Inadequate salaries & 40 & 80 & 38 & 76 \\
Shifting classes (double session) & 20 & 40 & 28 & 56 \\
Teachers residing far from schools & 18 & 36 & 26 & 52 \\
Low level of professional knowledge & 11 & 22 & 20 & 40 \\
Working for long time in the same school & 21 & 42 & 4 & 8 \\
Lack of frequent visits by education officers & 17 & 34 & - & - \\
Failure to fulfill teachers' needs and demand & 25 & 50 & 26 & 52 \\
\hline
\end{tabular}

From data in Table 4 causes of teacher misconduct were summarized and categorized into economic, social, managerial, and educational related factors:

\subsubsection{Economic related factors}

Low income and inadequate salaries were claimed to be the major causes of teacher misconduct. The majority of the teachers regardless of location of their schools believed that inadequate salaries and low income influenced teachers to engage in misconduct. Teacher respondents indicated that since salaries and their income were not satisfactory teachers were forced to engage in private activities to supplement their income. Teachers spent official hours in self-initiated activities. For instance, during interviews held with SMC representatives it was revealed that in the rural settings teachers had small plots of land to attend to, and some kept livestock such as pigs, goats, and cattle, while others in particular female teachers made and sold local brews in local pubs. These findings are in line with Hallak and Poisson (2005) and Anangisye (2006) who disclose that low salaries are prime causes of dissatisfaction amongst most of the teachers which consequently, results into teachers' violation of code of professional conduct.

In urban areas, on the other hand, it was disclosed that the majority of teachers had taken loans from various financial institutions such as Pride Tanzania and National Microfinance Bank (NMB) which led to their monthly salary deduction to pay for the loans. The interviewed participants particularly WECs and headteachers revealed that most of the teachers spent the loaned money in unprofitable ways such as drinking alcohol. Since teachers had their small monthly salaries deducted, most of them found themselves remaining 
with little money. Therefore, to save their lives teachers opted for petty businesses such as selling snacks, ice cream, running salons and weaving clothes even when the lessons were underway.

\subsubsection{Social related factors}

Poor living environment and residing far from school compounds contributed also to teachers' involvement in misconduct. Teacher respondents indicated that shortage of teacher houses forced them to rent houses in places that risked their professional behaviours. Due to scarcity of houses, particularly in urban areas teachers had rented houses close to night clubs and bars. It was believed that living in such environment tempted them into drunkenness and prostitution. This finding confirms the previous study by Bennell and Mkyanuzi (2005) who asserted that the overall quality of environment in which teachers live powerfully affects the overall quality of teachers' behaviour. Also, residing far from school contributed to teachers' lateness. Residing far from school compounds was attributable to either lack of quality houses for teachers or lack of social services around the schools.

\subsubsection{Managerial factors}

Increase in misconduct among teachers was influenced by lack of frequent visits to schools by education officers, in particular school inspectors and TSD Officials. Findings indicated that rural schools were rarely visited by school inspectors and TSD Officials compared to their counterpart urban schools. During an interview the District Chief School Inspector of Sumbawanga Rural complained that:

“...It takes a long time for school inspectors to visit teachers in rural schools because the funds we get from the Ministry are not satisfactory to let us visit all the rural schools. Also most of rural schools are located in remote areas which are very hard to reach...Indeed, this contributes to teachers' misconducts since teachers in rural areas feel isolated from the top educational authorities thus they lose job commitment and breach the code of conduct"

It is evident that location of most of the rural based schools (remoteness) and shortage of funds to facilitate the school inspection exercise make it difficult for school inspectors in such areas to fulfill their responsibilities effectively.

More importantly, teacher respondents uncovered that management at both ministerial and district levels failed to fulfill teachers' needs. Teachers felt neglected by the authorities and perceived that they were unfairly treated in terms of access to promotion, transfers and transfer allowances, salary arrears and other benefits. In turn, this condition affected teachers' morale and job commitment.

Furthermore, data indicated that in both rural and urban schools teachers were not in support of the system of shifting classes (double session). Double session required teachers to come back to school after getting their lunch and stay at school until $4.00 \mathrm{pm}$. Similarly, during interviews held with participant headteachers it was revealed that double session encouraged lateness and absenteeism among teacher. This was because most of the teachers resided away 


\section{Macrothink}

International Journal of Education

ISSN 1948-5476

2013, Vol. 5, No. 1

from their schools thus came late during the afternoon sessions or did not return to school at all.

\subsubsection{Professional knowledge related factors}

Inadequate professional knowledge among teachers was also identified to be a responsible factor for teacher misconduct. Responses in the questionnaires revealed that teachers especially those recruited during the implementation of PEDP between 2002 and 2007 had low professional knowledge. Also, most of interviewed headteachers disclosed that during the period between 2002 and 2007 a large number of people were enrolled into teachers' colleges and were then trained for a short time. This was done so as to meet the demand of teachers for increased pupil enrolment in public primary schools. As a result, teachers recruited during that cohort were less competent. Most of them have failed to maintain teaching ethics by involving themselves in misconducts such as unethical dressing, drug abuse, sexual misconduct, and drunkenness.

\section{Conclusion}

Teacher misconduct is a problem of great concern in both rural and urban schools that affects teachers' work performance, the teaching and learning process, and the quality of education at large. This situation brings an implication that more effort by educational administrators at both institutional and district levels is needed to address the problem of teacher misconduct in their respective areas.

\section{Recommendations}

Based on the research findings and conclusion of this study, the following recommendations are made:

5.1 The Ministry of Education and Vocational Training should work on the teachers' living and/or working condition since such variables bring much influence on teachers' professional behaviour. More importantly, embarking on professional training and induction programmes for the newly recruited and partially trained teachers to address the challenges that most of the public primary school teachers encounter in maintaining professional ethics is of great significance.

5.2 The Government through the Ministry of Education and Vocational Training should provide both the District School Inspectorate Unit and Teachers' Services Department with adequate funds so as to enable them to visit and inspect large number of schools especially in rural settings. 


\section{References}

Anangisye, W.A.L. (2006). Educating teachers the ethical dimension of teacher professionalism in Tanzania. PhD Unpublished Dissertation, University of Edinburgh, Edinburgh.

Anangisye, W.A.L., \& Barrett, A. M. (2006). Professional identity and misconduct: Perspective of Tanzanian teachers. Southern African Review of Education, 11(1), 5-22.

Barrett, A.M. (2004a). Teacher accountability in context: Tanzania primary school teachers' perception of local community and educational administration. Compare Forthcoming.

Barrett, A.M. (2004b). Africa teacher narratives in comparative research. Mimeo.

BBC News. (2009, February 13). Shock as Tanzania teachers caned. Retrieved February 14, 2009, from http://www.news.bbc.co.uk/2/hi/africa/7888158.stm

Bennell, P., \& Mkyanuzi, F. (2005). Is there any teacher motivation crisis in Tanzania? Dar es Salaam: HR-CONSULT.

Best, J.W., \& Khan, J. V. (2006). Research in education (10 ${ }^{\text {th }}$ ed). Boston: Allyn and Bacon

Boimanda, A.Y. (2004). Decline in the professional code of conduct among the teachers in Tanzanian public schools: Causes and Implication. M.A Unpublished Dissertation, University of Dar es Salaam.

Bray, M. (1999). The shadow education system: Private tutoring and its implications for planners. Paris: IIEP- UNESCO.

Bray, M. (2003). Adverse effects of private supplementary tutoring: Dimensions, implications and government response. Paris: IIEP- UNESCO.

Chapman, D. (2002). Corruption and education sector. Washington: USAID.

Cohen, L., Manion, L., \& Marrison, K. (2011). Research methods in education $\left(7^{\text {th }}\right.$ ed). London: Routledge Taylor \& Francis Group.

Creswell, J. W. (2009). Research design: Qualitative, quantitative, and mixed methods approach ( $3^{\text {rd }}$ ed). Los Angeles: SAGE Publications.

HakiElimu. (2010). Restoring teacher dignity. Dar es Salaam: HakiElimu.

Hallak, K., \& Poisson, M. (2007). Corrupt schools, corrupt universities: What can be done? Paris: IIEP.

Kuleana. (1999). The state of education in Tanzania: Crises and opportunities. Dar es Salaam: Kuleana Centre for Children.

Patrinos, H. A., \& Kagia, R. (2008). Maximizing the performance of education systems: The case of teacher absenteeism. Paris: UNESCO.

Shakeshaft, C. (2004). Educator sexual misconduct: A synthesis of existing literature. New 
York: Hofstra University and Interactive INC.

Teachers' Service Department (TSD). (2008). Teachers dismissed from service for various disciplinary offences between 2003 and 2007 in the country.

Transparency International. (2007). Corruption in education sector: Working paper.

Van Nuland, S., \& Khandelwal, P. (2006). Ethics in education: The role of teacher codes. Paris: UNESCO.

\section{Copyright Disclaimer}

Copyright reserved by the author(s).

This article is an open-access article distributed under the terms and conditions of the Creative Commons Attribution license (http://creativecommons.org/licenses/by/3.0/). 